mansasa

glyndŵn

Glyndŵr University

Glyndŵr University Research Online

Theology

Theology

$1-1-2003$

\title{
Born in difficult times: the founding of the Volksmission and the work of Karl Fix
}

B Rockle

William K. Kay

Glyndwr University, w.kay@glyndwr.ac.uk

Follow this and additional works at: http:// epubs.glyndwr.ac.uk/theo

Part of the History of Religion Commons, and the Religious Thought, Theology and Philosophy of Religion Commons

German Pentecostalism, Second World War, Karl Fix This is an electronic version of the published article that was originally published in the Journal of the European Pentecostal Theological Association in 2003, the journal website is available at http://www.eptaonline.com/. Copyright $(\subset$ 2003 author. Reproduced here by kind permission of the publisher and author.

\section{Recommended Citation}

Röckle, B., \& Kay, W.K. (2003) 'Born in difficult times: the founding of the Volksmission and the work of Karl Fix' Journal of the European Pentecostal Theological Association, 23, 72-101

This Article is brought to you for free and open access by the Theology at Glyndŵr University Research Online. It has been accepted for inclusion in Theology by an authorized administrator of Glyndŵr University Research Online. For more information, please contact d.jepson@glyndwr.ac.uk. 


\title{
Born in difficult times: The founding of the Volksmission and the work of Karl Fix
}

\author{
Bernhard Röckle and William K Kay ${ }^{1}$
}

\begin{abstract}
Summary
While in 1933 Adolf Hitler emerged from the brown quagmire of National Socialism to become Chancellor of the Reich and to establish his totalitarian state, a New-Testament apostolic church developed in the same city. Its leader, Karl Fix, bravely offered Hitler resistance.
\end{abstract}

Neither the ban on public gatherings issued in 1934, nor the permanent control by the GESTAPO could quench the burning zeal of the new converts. In 1934, many more than 1,000 participants were counted in the services; many of them experienced miraculous healings.

Through his literature mission, Fix was able to distribute around two million tracts in more than 12 countries. Thus the movement rapidly spread beyond the German borders. Encouraged by his prophetic view, Fix frankly warned the people of the self-proclaimed "Fuehrer".

The Swiss historian Walter Hollenweger, whose standard work Enthusiastisches Christentum - Die Pfingstbewegung in Geschichte und Gegenwart published in 1969, which, in its translation of 1997, was entitled Pentecostalism Origins and Developments Worldwide, merely mentions the Volksmission in a marginal note without dealing with its historical significance.

This article, after giving a short survey of how the German Pentecostal Movement came into being, points out the contribution of the Volksmission, focusing on its establishment over the years between 1933 and 1945. The theology of the Volksmission, which is classically Pentecostal, awaits a further article.

\section{The Roots of the Pentecostal Movement in Germany}

\subsection{Holiness Movement and Gemeinschaftsbewegung Clear the Way}

The German Pentecostal Movement has its roots in the German "Gemeinschaftsbewegung" ["Fellowship Movement"], which, in the 1870s, was strongly influenced by the Holiness Movement of England. Several German theologians used to attend the Oxford conferences. Moody and Sanky had brought the Evangelistic Movement to the British Isles. The movement quickly spread to Germany. The "Deutscher Verband für Gemeinschaftspflege und

\footnotetext{
${ }^{1}$ Bernhard Röckle is Pastor of the Volksmission church at Geislingen, Germany, a member of the Volksmission Executive Council, engaged in an international ministry and active in the political Partei Bibeltreuer Christen PBC. Email: Bernhard-Roeckle@t-online.de William K Kay Professor of Theology at Glyndwr University.

Email:w.kay@glyndwr.ac.uk
} 
Evangelisation" ["German Society for the Cultivation of Fellowship and Evangelism"], the so-called "Gnadauer Verband", served as a broad channel for the spiritual revival that was then bursting forth everywhere. The necessity of salvation through personal repentance and faith, as well as the necessity of personal sanctification, was emphasized in the sermons of that time. Conferences for believers were held, Bible study groups developed and new missionary societies were founded.

\subsection{R. A. Torrey at the Annual Conference of the Evangelische Allianz}

In August 1906, the American Evangelist Dr. Reuben Archer Torrey (1856-1928) preached at the annual conference of the Evangelische Allianz in Blankenburg (Thuringia) on the "Second Blessing" or "Baptism in the Holy Spirit", which, according to Acts 1:8, he interpreted as the event of receiving the "Power from on High for being a Witness". 2 One of the participants was General Lieutenant von Viebahn. He witnessed having received an entirely fresh power for evangelistic service. New revivals were the result.

\subsection{Jonathan Paul and Emil Meyer visiting Thomas Ball Barratt}

In the spring of 1907, Jonathan Paul ${ }^{3}$ travelled to Norway, in order to get to know the Pentecostal Movement in Christiana/Oslo founded by T. B. Barratt (1862-1940). ${ }^{4}$ In 1896, Paul had already published a book entitled Ihr werdet die Kraft des Heiligen Geistes empfangen ["You will be Endued with the Power of the Holy Spirit"]. In this book, he had stated already 10 years before the events in "Azusa Street", 5 took place:

As there is such a lack of a fullness of the Spirit today, there is also a lack of spiritual power and of the gifts of the Spirit. ${ }^{6}$

Having returned from Norway, Paul wrote in his booklet Zur Dämonenfrage ["On Demonology"],

At those Pentecostal conventions in Christiana, I found a revival movement dealing with deeper purification through the blood of Jesus and with the endeavour to experience a stronger outpouring of the Spirit and His gifts. ${ }^{7}$

Besides Paul, the leader of the Hamburg city mission, Emil Meyer, undertook a journey to Norway in 1907. Later, he was to have a great influence on Karl Fix, the founder of the

\footnotetext{
${ }^{2}$ Steiner, L., Mit folgenden Zeichen Eine Darstellung der Pfingstbewegung, Verlag Mission für das volle Evangelium, Basel, 1954, p. 17

${ }^{3}$ Jonathan Paul (1853-1931) became vicar of Ravenstein after having completed his university studies. In 1899 , he started serving as a free evangelist. An extensive study on his life and work has been compiled by Dr. Ernst Giese (Giese, E., Jonathan Paul, ein Knecht Jesu Christi Leben und Werk, Missionsbuchhandlung und Verlag, Altdorf bei Nürnberg, 1965)

${ }^{4}$ Wessler, G., "Ein Stück Kirchengeschichte", 75 Jahre BFP freikirchliche Pfingstbewegung in Deutschland, Erzhausen, 1982, p. 4

${ }^{5}$ The report about this remarkable Revival in Los Angeles has been translated by Witt, E., in Wie Pfingsten nach Los Angeles kam (German translation of the report written by Frank Bartlemann), Philadelphia-Verlag Leonberg, Leonberg, undated

${ }^{6}$ Paul, Jonathan, Ihr werdet die Kraft des Heiligen Geistes empfangen, Deutsche Evangelische Buch- und Tractatgesellschaft, Berlin, 1896, p. 187

${ }^{7}$ according to Krust, C., 50 Jahre Deutsche Pfingstbewegung Mühlheimer Richtung, Missionsbuchhandlung und Verlag, Altdorf bei Nürnberg, 1958, p. 46
} 
Volksmission. From Norway, Meyer brought two lady missionaries back to Germany. They were Dagmar Engström ${ }^{8}$ and Agnes Telle, who had received the gift of speaking in tongues.

\subsection{Heinrich Dallmeyer and the Norwegian Missionaries in Kassel}

In Hamburg, Heinrich Dallmeyer from Kassel heard those missionaries. He invited them and started a series of conventions in the home of the Blue Cross Temperance League on 7 July 1907.

Even those who later became their opponents reported the meetings to have been calm and harmonious in the beginning. Thus, Christian Krust quotes from Otto Kaiser's Erlebnisse und Erfahrungen mit der Pfingstbewegung ["Experiences and Encounters with the Pentecostal Movement"] (1948, pp. 8-10):

On Wednesday afternoon, I attended the Bible study held by brother Dallmeyer, in which, all of a sudden and unexpected by everybody, one of the Norwegian ladies spoke in tongues. Her messages were translated. They almost exclusively were testimonies of the Scriptures, which were directed to the congregation in shattering reverence and seriousness. The atmosphere during the meeting was, in spite of the serious messages, thus that one thought to be in heaven, directly addressed by God. ${ }^{9}$

\subsection{The Movement goes astray}

Later, though, the services took on a noisy and restless character. The press reported on these meetings; often, people would gather in front of the Blue Cross home yelling and mocking those participating in the meetings. On the other hand, several started believing in Christ, while others who had been sick were healed.

During this time, Dallmeyer had an experience, the beginning of which Paul Fleisch describes as follows:

On the nineteenth, a certain brother, while praying for Christ to come back again, thought, "The Lord will not return as soon as that." Suddenly the Spirit ascended upon him, he fell to the floor like dead feeling an extreme pain in his chest. When the congregation had left, he received about 32 revelations from 10:30 p.m. to 1 a.m. Each one of these closed with the Spirit's instruction to wait. After, 2-3 minutes the next revelation was given. ${ }^{10}$

Ernst Giese comments:

In this case, the following questions must be asked: Had Dallmeyer forgotten the Word of Scripture given in 1 Corinthians 14:32, "The spirits of prophets are

\footnotetext{
8 Kurt Hutten (1901-1979), reports the family name to be "Gregersen" in Hutten, K., Seher Grübler Enthusiasten Sekten und religiöse Sondergemeinschaften der Gegenwart, (Quell Verlag, Stuttgart, $9^{\text {th }}$ edition 1964), p. 490

9 ibid. p. 47

${ }^{10}$ Fleisch, Paul, Geschichte der Pfingstbewegung in Deutschland von 1900 - 1950, Verlag der FranckeBuchhandlung, Marburg, 1983, p. 38 (This book was published previously with the title Die Pfingstbewegung in Deutschland: Ihr Wesen und ihre Geschichte in fünfzig Jahren, Heinriche Feesche Verlag, Hannover, 1957)
} 
subject to the control of prophets"? Should this man not have realized by the strange ambiguity he was in, and by the peculiar and medially-occult manner in which he made his utterances, being prostrated on the ground, and, above all, by Schrenk's warning to beware of false prophecy, that in this night, seeking a private revelation, he had fallen victim to the occult? Several times, the Holy Spirit of God had warned him by the interpreted messages in tongues given by the Norwegian ladies to "make a difference between the genuine and the false".

From now on, the Kassel movement went astray. Fleisch and Giese describe the attitudes of the Norwegian ladies differently. ${ }^{12}$ Both agree, though, that the ladies had warned the congregation that something other than the Holy Spirit might creep in. Some newspaper articles, published by sensation-seeking reporters, attracted such masses of onlookers that in the end the police had to guard the place with their dogs in order to keep things in order. Finally, Dallmeyer was urgently asked by the police to close the meetings that had been held daily for four weeks.

1.6 Jonathan Paul is baptised in the Holy Spirit, while Dallmeyer dissociates himself from the Movement

As visitors from all over Germany had come to Kassel, the experience of being baptized in the Spirit spread rapidly. On 15 September 1907, Pastor Jonathan Paul received the Baptism "in the way described in Ezra 8:23,". ${ }^{13}$

While this movement spread, conflicts arose at the same time in the Gemeinschaftsbewegung. Heinrich Dallmeyer dissociated himself; his brother August states in the magazine Reichsgottesarbeiter:

The gifts manifested in this movement are not truly spiritual; without exception they have been wrought by the Devil. By these, Satan has made his way into the fellowship of the Saints. In the Los Angeles movement, a strong mendacious spirit is at work. ${ }^{14}$

\subsection{First Pentecostal Conference in Hamburg}

From 8 to 11 December 1908, representatives of the new movement met for the first time to hold a conference in Hamburg at the beach mission centre. There were also guests from England, Holland, Norway, Sweden and Switzerland. Krust lists the following names: Mr. Cecil Polhill, London; Alexander A. Boddy, Sunderland (vicar); T. B. Barratt, Christiana (pastor); J. Paul (pastor), J. Koch (evangelist), Blankenburg, S. E. Cooke-Collis, Switzerland; G. R. Polmann (evangelist), Amsterdam; P. Oltmann (Amsterdam); Emil Humburg, Mühlheim a. d. Ruhr; evangelist Edel, Brieg; Andrew Johnson, Orebro, Sweden; Voget (pastor), Bunde; E. Meyer (beach mission), Hamburg; and others. ${ }^{15}$

\footnotetext{
${ }^{11}$ Giese, Ernst, Und flicken die Netze: Dokumente zur Erweckungsgeschichte des 20. Jahrhunderts/edited by Prof. O.S. von Bibra, Ernst Franz Verlag, Metzingen, 1987, p. 58

12 ibid. p. 67, Fleisch op. cit. p. 39

13 Fleisch op. cit. pp. 57-60 and Giese, Ernst, Jonathan Paul, Ein Knecht Jesu Christi Leben und Werk, Missionsbuchhandlung und Verlag Altdorf bei Nürnberg, 1965 ( $2^{\text {nd }}$ edition $)$, pp. $128-130$

${ }^{14}$ Ibid p. 66

${ }^{15}$ Krust, C., 50 Jahre Deutsche Pfingstbewegung, op. cit. p. 59
} 
A decision was also made at this conference to publish a periodical paper for the purpose of orientation concerning the latest spiritual movement: Pfingstgrïße ["Pentecostal Greetings"]. J. Paul was asked to be the editor. ${ }^{16}$

The first statement given on the topic of speaking in tongues is quite remarkable, as it shows that the item of "initial evidence" was no subject for discussion then:

Let nobody think that speaking in tongues is a "Shibboleth" for us and that we consider any child of God that has not received this gift less valuable. This is absolutely not the case ... Neither do we consider speaking in tongues in itself proof of the infilling of the Spirit. We know that we can judge by the fruit what kind of person we are dealing with (Matthew 7:16). ${ }^{17}$

Krust sums up his evaluation by saying that, "by this conference, the German Pentecostal Movement has been brought into being" and that the beginnings of its further development must be dated there. ${ }^{18}$ Jonathan Paul, the preacher Eugen Edel (Brieg in the east) and Emil Humburg (Mühlheim a. d. Ruhr in the west) would finally emerge as the leaders of the movement. Emil Meyer published an address to those who had not been able to take part in the conference with the request to read the Pfingstgrïße. ${ }^{19}$

In the meantime, the movement spread all over Germany. The Mühlheim Pentecostal conferences starting in July 1909 played an important part there. While around 1700 people attended the first conference taking place from 14 to 16 July 1909, as many as 2500 took part in the second conference.

\subsection{The Berliner Erklärung ["Berlin Declaration"]}

Around 60 leading brethren of the Gemeinschaftsbewegung met in Berlin on 15 September 1909. Because of the facts before them they felt obliged to make a definite and final declaration that the spiritual gifts that had occurred in the Pentecostal Movement did not have their origin in the Spirit of God but in "demonic spirits coming from the Abyss". A nineteenhour meeting resulted in the so-called Berliner Erklärung, part of which states:

This movement is inseparably connected with the movement of Los Angeles, Christiana, Hamburg, Kassel and Großalmerode... The so-called Pentecostal Movement has not come from above, but from below; a great number of manifestations are the same as in the Spiritist movement. In the Pentecostal Movement, there are demons at work, which, cunningly directed by Satan, confuse lie and truth, in order to deceive God's children. There are many cases, where the so-called "spirit-gifted" ones later proved to be demon-possessed.

Our conviction that this movement is from below, can neither be put in question by the personal faithfulness and devotion of individual leading brethren, nor by the healings, tongues, prophecies... Many times before, such manifestations used to be connected with similar movements, e.g. with the Irvingites, even with Christian Science and Spiritism. The spirit dominating this movement introduces

\footnotetext{
${ }^{16}$ ibid. p. 64

${ }^{17}$ Pfingstgrüße vol. 1, February 1909, quoted in Krust, op. cit. p. 64

${ }^{18}$ Krust, op. cit. p. 65

${ }^{19}$ Fleisch op. cit. p. 82
} 
himself through the Word of God, which will be pushed into the background by so-called "prophecies" (compare 2 Chronicles 18:18-22)... The spokespersons conveying these prophecies are mostly women. In many situations, this has against clear Biblical instructions - resulted in women, even young girls, being in central leadership positions of the movement.... We are not awaiting a new Pentecost; we are awaiting our coming Lord. Thus, we herewith ask all our brethren for the sake of the Lord and of His work, which Satan intends to destroy: Keep away from this movement! Whoever has fallen victim to the power of this spirit is asked to break with it and to ask God for forgiveness and deliverance. ${ }^{20}$

A consensus was not thought to be a possible; the only way to save the Gemeinschaftsbewegung was seen in a definite separation from the "demonic" Pentecostal meetings. Yet this verdict rested partly on the fact that only brethren opposing the Pentecostal Movement had been invited. The sentence was pronounced without even hearing those who were accused. After confirming this verdict in the following meeting of the Gnadauer Verband, every member was obliged not to co-operate with any brethren belonging to the Pentecostal Movement. Any violation of this decision was "not in accordance with the position of the Gnadauer Verband". ${ }^{21}$

\subsection{The Mühlheimer Erklärung ["Mühlheim Declaration"]}

At their third conference, taking place in Mühlheim in October 1909, the members of the Pentecostal Movement responded to the Berliner Erklärung by issuing the Mühlheimer Erklärung, in which, among others, the following statements have been made:

We thank the Lord for the present spiritual movement. We consider this the beginning of a divine answer to the many years of believing prayer for a worldwide revival. Thus, we recognize this movement as a gift from above, not from below... Concerning several details, we want to clearly state that, as a matter of course, not only divine, but also soulish, respectively human, and possibly even demonic features become manifest. Yet, this is characteristic for any revival. ${ }^{22}$

Since 1910, in spite of various further meetings and declarations, the Pfingstbewegung had become more or less isolated. On 2 February 1914, the "Christliche Kolportage-Gesellschaft mit beschränkter Haftung zu Mühlheim-Ruhr" ["Society for the Spread of Christian Literature, Ltd., Mühlheim-Ruhr"] was founded. ${ }^{23}$

\footnotetext{
${ }^{20}$ Krust op. cit. pp. 67-71

21 ibid. p. 71

22 ibid. p. 73-77

${ }^{23}$ On 17 February 1938 the Reich's Minister for Religious Affairs issued the following statement, "According to the law for the protection of the nomenclature of the NSDAP as of 7 April 1937, RGB1. I, p. 442, the terms used by the German National-Socialist Workers' Party, its subdivisions, as well as by its associated unions, for its office-bearers, structures, institutions and symbols, must not be used anywhere else, neither individually nor communally."

For this reason neither using the name "Bewegung" nor "Reichs-Bewegung" was allowed any more, the Gemeinschaftsverband being legally represented by the "Missionsgesellschaft m.b.H. Mühlheim-Ruhr" that had so far been called "Deutsche Pfingstbewegung," now renamed "Christlicher Gemeinschaftsverband G.m.b.H. Mühlheim Ruhr" with effect from 29 April1938 (Krust p. 174).
} 


\section{The Founding of The Volksmission in Berlin}

2.1 Hindenburg issues the Emergency Decree "Zum Schutz von Volk und Staat" ["For the Protection of the People and the State"]

The Weimar Republic ${ }^{24}$ that had come into being in 1919, when World War I (1914-1918) was over, was being shaken by severe economic and political crises during its short existence of only 15 years. Finally, at the instigation of Hitler, the 84-year-old German president Paul von Hindenburg issued the emergency decree "Zum Schutz von Volk und Staat" on 28 February 1932. This decree meant the end of liberty guaranteed by the constitution. The KPD (Communist Party of Germany) was immediately forbidden, while political opponents would be eliminated without any legal proceedings.

\subsection{Hitler passes the "Ermächtigungsgesetz" ["Enabling Act"]}

On 30 January 1933, the political right wing parties had finally reached their goal Hindenburg appointed Adolf Hitler German Chancellor. Any reservations on the side of the aged military hero would be appeased by referring to the enforced coalition with the NSDAP and to the present constellations in parliament. "Democracy had already died, yet, it was not sure in which direction it would fall," an observer mentioned later. And in fact, Hitler immediately set about terminating democracy for good. He had new elections called - the last ones ever -, as he proudly announced - and, in order to support his party, he applied all instruments of power, giving all the other parties over to the terrors of the $\mathrm{SA}^{25}$ without any protection. He used the arson of the Reichstag as an opportunity to crush the Communist Party. Still, he did not have the absolute majority yet, as the NSDAP had not won more than $44 \%$ of the votes. This meant that Hitler needed a coalition partner for a cabinet reshuffle. He wanted more than an absolute majority, though. With the help of a two-thirds majority, he intended to annul the constitution "legally".

We uphold the principles of a nation under the rule of law, of equality, of social rights that have been laid down in the Weimar constitution. We German Social Democrats pledge ourselves solemnly in this historic hour to the principles of humanity and justice, of freedom and socialism. No enabling act can give you power to destroy ideas which are eternal and indestructible

For the next 12 years, this ought to have been the last free speech held in Germany. This was the reason given the SPD member and party spokesman Otto Wels (1873-1939) when he explained his party's refusal of the Enabling Act. Nevertheless despite such political opposition, Hitler gained the two-third majority he wanted. ${ }^{26}$

\footnotetext{
${ }^{24}$ A federal republic of 17 states being ruled both as a whole and in each individual state according to democratic and parliamentary principles. The legislative body was the Reichstag with the very limited assistance of the Reichsrat. The highest executive body was the German president who was authorized to appoint the German chancellor and the German government.

${ }^{25} \mathrm{SA}=$ "Sturmabteilung" ["Storm Troops"]; the task force of the NSDAP having had military training

${ }^{26}$ Schildt, Gerhard, Geschichte Europas, Westermann, Braunschweig, 1988, pp. 240-247
} 


\section{3 "Gleichschaltung" ["Forced Coordination"]}

The wave of arrests reached all other political parties - arrests, not carried out by organs of the state, but by the $\mathrm{SA}$ or $\mathrm{SS}^{27}$, accompanied by dreadful maltreatment and consignment to the first concentration camps. The parties, robbed of their heads, having become insecure, split, being spied on, gave in and dissolved. KPD and SPD were banned. Political opposition ceased.

The trade unions were also smashed, the constitutions of the individual German states done away with, the press was "equalized", while education and arts were uniformly orientated towards the principles of the national socialist government. Only forcing the churches into line was more difficult for the dictator. In Protestantism, the so-called "Bekennende Kirche" ["Confessing Church"] came into being ${ }^{28}$ and firmly resisted the Gleichschaltung. So did the Roman Catholic Church to a certain extend as well, ${ }^{29}$ after having been confused first by the offer of a generous concordat, a treaty between the German Reich and the Holy See. All these oppressive circumstances made up the political situation in which the first public meeting of the Volksmission took place in Berlin on 1 January 1934.

\subsection{Karl Fix comes to Know Christ}

Karl Friedrich Fix (1897-1969), the founder of the Volksmission entschiedener Christen was born August $14^{\text {th }} 1897$ in Kupferzell near Künzelsau in the state of Baden-Württemberg. He spent his childhood in Löwenstein near Heilbronn. As a young person, he was enthusiastic about philosophy, especially about F. Nietzsche. Five months after having finished his apprenticeship as a textile businessman in March 1914, he took part as a volunteer in World War I ${ }^{30}$ yet, at the end of the War, as a 21-year-old, he was "sick in body, soul and spirit". ${ }^{31}$ Attracted by the SPD slogan "No more War!", he made his way into politics and became a socialist. Having been a gifted writer from his earliest youth, he became a journalist with the "Heilbronner Stimme". ${ }^{32}$ In this job, he functioned as a local reporter, a film critic and a representative of the press. From 1928-1932 he served as a "reporter of an uncountable number of political meetings." 33 Suffering from a serious cirrhosis of the liver caused by

\footnotetext{
${ }^{27}$ SS = "Schutzstaffel" ["protection squad"] originally served as Hitler's bodyguards. After the "Röhm Coup" and due to Himmler's promotion, they gained the entire power of government. They were to cultivate the "Master Race" in Europe

${ }^{28}$ Resistance church which in 1933 started to turn against the Deutsche Christen, the church of national socialist orientation. Led by Martin Niemöller (1892-1984) and Dietrich Bonhoeffer (1906-1944), the "Pfarrernotbund" ["Pastor's Emergency League"] was founded on 21 September 1933 . They met for the first free synod in 1934 to bravely oppose the government's presumptuousness concerning questions of faith and conscience. After the end of the War, the heads of the "Bekennende Kirche" played a decisive part in re-building the structure of the church.

${ }^{29}$ Johannes Baptista Sproll, head of the Rottenburg diocese, may serve as an example. From the beginning, he was a special object of GESTAPO control, as he repeatedly preached against the national socialist world view. On 10 April 1938 he did not take part in the plebiscite on Austria's entry. Jesuit Alfred Delp is also worth mentioning. He was a member of the "Kreisau Circle", where on the estate of Duke Helmut von Moltke some opponents of national socialism used to meet in order to discuss a re-structuring of Germany in the spirit of Christianity after the War (see also chapter 13 "Die Kirchen und das Dritte Reich" in Albers, W., Kurswissen Kirche - Staat - Politik, Klett Verlag, Stuttgart/Dresden, 1994, pp. 115-134.

30 Fix, K., "Aus dem Kleinsten sollen tausend werden..." Ein Zeugnis über das Werden unserer Schriftenmission, Verlag Deutsche Volksmission entschiedener Christen, Schorndorf, II. Auflage 1957, p. 4

${ }^{31}$ Fix, K., Preiset mit mir den Herrn 30 Jahre Volksmission entschiedener Christen Berlin 1. Januar 1934 bis 1964, Verlag Deutsche Volksmission entschiedener Christen, Schorndorf, 1964, p. 5

${ }^{32}$ Gast, H.J., "Heimat für Heimatlose" in 60 Jahre Volksmission Berlin 1934 - 1994 Festschrift, (Berlin, Volksmission Berlin, 1994), pp. 11-12

${ }^{33}$ Fix, K., “Aus dem Kleinsten sollen tausend werden...” op. cit. p. 5
} 
excessive drinking, ${ }^{34}$ people had given him up. ${ }^{35}$ In his tract, entitled Volle Erlösung in Christo Jesu he, who had once written satirical stories against the Christian faith, confessed: ${ }^{36}$

From my earliest youth, my entire life meant restlessness, searching endlessly without finding. Eagerly, I would devour all kinds of knowledge, I would miss out on sleep and on fulfilling my duties. Often, I was depressed, considering suicide. ... My despair I fought by using drugs, of which I needed certain doses to be able to live. I was eaten up by poisonous bondage and addictions - a hopeless case. A child saved me from committing suicide. ${ }^{37}$

Many people contributed to his conversion. Karl Fix particularly mentions in his book entitled Preiset mit mir den Herrn his Christian mother and a cousin who had been praying for him for over 15 years, as well as a leading Mennonite. In his characteristic expressiveness, he describes how, sitting on a bench near his wife's grave in the churchyard, ${ }^{38}$ this Mennonite brother kept repeating the same sentence over and over again, speaking it right into the darkness of Fix's life, "And even, if no one else will be able to help you any more, there is One who can still help you - it is the Lord Jesus Christ, the same, yesterday and today and for ever." This preacher also supplied Fix with Christian literature. There was one booklet by Fritz Binde $^{39}$ called Vom Atheisten zum Evangelisten. When Fix had studied it, he wrote,

Reading this booklet, the Law of Sin and Death became totally clear to me inwardly - my being absolutely lost and entangled in the bondages of darkness. On the other hand there is only one way out: The redemption accomplished by our Lord Jesus Christ. ${ }^{40}$

Fix wanted to attend evangelistic meetings held by Emil Meyer in Kassel but he was so weak that he had to find a hotel first in order to take his strong medication. Dr. Bircher-Benner, the famous doctor from Zurich, had already confirmed to him in 1925, that his life only hung by a thread. $^{41}$

For 8-10 days, Evangelist Meyer prayed with him daily, until, as he writes, he experienced the power of God making him whole in body, soul and spirit. Fix remembers:

Every day we had at least two services, counselling sessions and prayer meetings. The Word of God that was being shared there had an immense impact on me.....

\footnotetext{
${ }^{34}$ Fix K., Bibel und Krankheit, (Karl Fix Verlag Volksmission entschiedener Christen, Vaihingen/Enz, 1951), p. 17

${ }^{35}$ Gast op. cit. p. 12

${ }^{36}$ Velke H., Erlebte Gnade, Missionsverlag Gottlob Ling, Bauschlott, $2^{\text {nd }}$ edition 1994, p. 18

${ }^{37}$ Grunewald E., "Segenstage in Berlin", Der feste Grund, No. 15, vol.6 (1 August 1935), p. 2. Fix gives tells his detailed biography in Frevel - Grauen - Grausen: Selbstmord, op. cit. pp. 40-45

${ }^{38}$ On February $14^{\text {th }} 1932$, after having been married for 10 years, his first wife Hermine died. Bereft of his wife, left alone with his 9-year-old boy, Fix fell into deep depressions (oral information given by his son Johannes Fix on 27 Mai 2001).

${ }^{39}$ Fritz Binde (1867-1921) had been a socialist and anarchist before coming to believe in Christ. After his conversion, he first worked with the Deutsche Zeltmission, the German tent mission, then he became an independent evangelist, counsellor and writer (Bauer H., and others, Eine Saat geht auf 75 Jahre Süddeutsche Vereinigung für Evangelisation und Gemeinschaftspflege 1910 - 1985, Stuttgart, Süddeutsche Vereinigung für Evangelisation und Gemeinschaftspflege, Stuttgart, 1985) p. 12

${ }^{40}$ Fix, K., Preiset mit mir den Herrn op. cit. p. 6

${ }^{41}$ Fix, K., “... und rufe mich an in der Not, so will ich Dich erretten!”, (Karl Fix Verlag Deutsche Volksmission entschiedener Christen, Schorndorf, 1946) p. 6
} 
The power of God came over me in such a mighty way that even other persons realised that something extraordinary had happened to me. During my years of despair I would not be able to find sleep for many, many a night in spite of taking the strongest drugs; I would rather see everything through clouds of depression. That night, though, was to be the first night in my life, in which I could not find any sleep for gladness and joy. Great things had happened - God had had mercy on $m !^{42}$

Fix followed Meyer's suggestion of accompanying him on his next evangelistic campaign to Berlin. Fix made his good relations to the press available for Meyer's purposes and helped him with his public relations. Soon, Meyer transferred to Fix his publishing business together with the responsibility for editing the periodical Gott mit uns ${ }^{43}$.

\subsection{Fix, the Founder of the "Deutsche Volksmission"}

For six months, rallies were being held "all over Berlin", beginning in the Garde-Hallen in Sophienstraße on 1 January 1933. Many signs and wonders happened there. Fix was allowed to give his first "testimony". Besides "gladness overflowing", Fix also speaks of difficulties in getting acquainted with the world of those believing in Christ:

There is such a vast amount of things to learn. You don't know them all - all those different groups and associations. You don't know the definition of "Methodist", "Baptist" and "Pentecostal". As an outsider, you do not have a clue of all those groups, the fences, the minor and major popes. I am very much ashamed to say that I did not know that in my Swabian home area there existed a place called "Möttlingen," 44 till I came to Berlin. ${ }^{45}$

In June 1933, Fix, for the first time, heard one of the brethren witness to the Baptism in the Holy Spirit. In spite of some resistance against the outward way of "getting it", his desire was according to Luke 4:18-19 “... the Spirit of the Lord is upon me as a holy anointing, commissioned and enabled to preach the gospel to the poor", which was to be fulfilled in the autumn of 1933 in one of the branches in Saxony. Fix describes this event:

It was the first time I met a group of believers as described in 1 Corinthians 14:26. Spiritual power was at work there, visions, tongues, revelations, interpretations. During one especially anointed prayer meeting, I heard God's call, "Whom shall I send? And who will go for Me?" And my heart echoed tremblingly and fearfully, "Lord, send me" (Isaiah 6:8). ${ }^{46}$

\footnotetext{
${ }^{42}$ Fix, K., Preiset mit mir den Herrn op. cit. p. 8

${ }^{43}$ Sommer G., Anfänge freikirchlicher Pfingstgemeinden in Deutschland zwischen 1907 und 1945, unpublished thesis presented to the department of theological history at the FTA, Gießen, April 1998, p. 56

${ }^{44}$ Through the ministry of Johann Christoph Blumhardt (born on 16 July 1805), the small village of Möttlingen near Calw experienced revival and repentance, which effected the whole of southern Germany. Detailed information is given in the report on the illness and healing of Gottliebin Dittus in Blumhardt's: Die Krankheitsgeschichte der Gottliebin Dittus in Möttlingen. Der Tatsachenbericht an die vorgesetzte Kirchenbehörde, 1844, (Verlag Goldene Worte, $15^{\text {th }}$ edition, Stuttgart, 1975)

${ }^{45}$ Fix, K., Preiset mit mir den Herrn op. cit. p. 9

46 ibid. p. 12
} 
Fix understood that the Lord had called him to start an independent "Faith Ministry" in Berlin, called "Deutsche Volksmission entschiedener Christen Berlin" ["German People's Mission of committed Christians"].

Inspired by 1 Timothy 2:4 ("God wants all men to be saved and to come to a knowledge of the truth.”) and 1 John 5:14-16, Fix outlines this commitment in his testimony as follows:

The reason for founding the Volksmission was to pray for people living in sin, bondage and sickness, and thus save body, soul and spirit... The purpose of being an evangelistic movement can never be to satisfy itself, but its calling is to save souls. Besides that, saving souls is the main prerequisite for being a biblical church. $^{47}$

\subsection{Public Meetings in Linienstraße}

Selma Bischof was a sister in Christ coming from the south of the state of Brandenburg. When she was in prayer, God gave her the inner impression that Karl Fix should found a church in the north-east of Berlin where the poorest used to live, and that this church should "be a manifestation of the full salvation in Christ". 48

The "Verein für Urchristen" ["Society for Early-Church Christianity"] provided a church hall for Karl Fix in the Linienstraße, which he could rent for several months for daily use. The first service took place on 1 January 1934. Every morning, there would be a prayer meeting, every night an evangelistic meeting. During the day, open-air meetings were conducted in the large Berlin back yards that were situated in the midst of blocks of up to 100 flats. Fix writes that about $95 \%$ of the over 1000 people that attended the services during the first year, experienced Jesus as their physician, while many others were set free from bondage and vices and were baptized with the Holy Spirit. ${ }^{49}$

\subsection{Volksmission Registered and Banned}

Although Fix had not intended to found an officially registered church in the beginning, he followed the advice of his hosts, an elderly couple, to do so. Thus, the founding of the church as a registered body of 35 members and about 75 friends took place on 27 June 1934. Only one week later, Fix was summoned by the police. The regional officer told him that according to section so-and-so his meetings were prohibited and that he should not dare to open up another business like that in Greater Berlin. ${ }^{50}$

For the time being, the church met in private rooms, until, after making enquiries and studying the Reich's law for weeks, the section, responsible for the ban was discovered: "Selling of, and dealing with, illegal medicine."

The president of the Berlin Pankow police explained to Fix after reading Fix's article Willst du gesund werden ["Do you want to get well?"] from Heilsbote No.7, that practising prayer for the sick had been the reason for the ban. Finally, the following agreement was made with

\footnotetext{
${ }^{47}$ ibid. pp. 13-14

${ }^{48}$ Gast, H.J., "Heimat für Heimatlose" op .cit. p. 12

${ }^{49}$ Fix, K., Volksmission entschiedener Christen Weg und Werk, (Verlag Deutsche Volksmission entschiedener Christen, Schorndorf, 1956), p. 9

${ }^{50}$ Fix, K., Preiset mit mir den Herrn, op. cit. p. 17
} 
the police chief: Meetings may only take place under the surveillance of the district police, and the congregation must consist of one third of friends, and two thirds of registered members. Open-air meetings were forbidden and the magazine Der Heilsbote banned.

Both members and friends were questioned by the GESTAPO, which meant an additional danger considering Karl Fix's socialist past. When Kuttler, an elderly brother in Christ, was questioned about Fix and his political background, he answered, "Earlier on, he was a socialist, but now we are involved in heavenly politics." Being asked what kind of politics, Kuttler answered, "We are waiting for the Lord's return." Contemptuously, the officer closed his file saying, "He will not come anyway." Fix remarks, "With this, I was not in danger any more." 51

Reviewing this time of oppression, Fix writes:

Let me state this very definitely considering Romans 8:28: Our work was stabilised by this ban. As for me, I was given enough time for prayer and for the Word of God, which the Lord especially used to talk to me about establishing churches in the biblical way. Yet, our members were strengthened as well. We certainly knew for sure who was one of us. The name of "Deutsche Volksmission entschiedener Christen Berlin" was officially registered then; ${ }^{52}$ we were on record with the government offices, they knew who we were and what our goals were. We had passed one of our first trials and tests. ${ }^{53}$

Fix only counted those as members of the church, who had been baptized in water ${ }^{54}$, and only these were admitted to the Lord's Supper. ${ }^{55}$ Erna Müller was a great help to Karl Fix. Originally, she had been a member of Miss von Treskow's girls' group. She joined the Volksmission in its very beginnings, was healed by faith from a terrible disease and married Karl Fix on 24 April 1935.

\subsection{Moving to Höchstestraße}

Fast growth and tension with the "Verein für Urchristentum" urged them to look for their own premises. Finally, a former dance hall could be rented in Höchstestraße 27. For some time, it had served as a storeroom for a fruit merchant. 200 people could be seated there. ${ }^{57}$ The dedication service was marked by joy overflowing, as Fix reports:

The praise session had hardly started, when our dear old brother Fritz Döhring suddenly started stuttering before breaking through speaking in tongues. The message I heard thrilled me: "Peace be with you! This is the way. Follow Me. You must enter the Kingdom of God through much tribulation. But do not be

\footnotetext{
${ }^{51}$ Fix, K., Preiset mit mir den Herrn, op. cit. p. 18

${ }^{52}$ In the constitution of the Berlin Church of the year 1938, section 8, it is stated that "The Volksmission has been registered with the Secret Police of Berlin C under V 3270/ V 3250/34 including a list of members and the creed, and listed in the NSDAP registry of societies under No. 1391/38 (Berlin Area).

53 ibid. p. 20

${ }^{54}$ It happened several times that baptisms were accompanied by healings. Helene Velke, who joined the Volksmission in 1935, relates in her autobiography Erlebte Gnade, p. 22, how she was spontaneously healed from a severe knee ailment that had been caused by calcification

${ }^{55}$ Fix, K., Preiset mit mir den Herrn op. cit. p. 34

56 ibid. p. 13

${ }^{57}$ Gast, H.J., Geschichte der Volksmission Berlin, unpublished typoscript, Berlin 2000, p. 1
} 
afraid. I, the Lord, I am with you. I will strengthen you..."... Psalm 36 literally describes the overwhelming experience we had: "They feast on the abundance of your house.... Drunk with heavenly delights!" My dear brethren experienced something similar. This way, we were made one in our blessed Holy Spirit for a definite mission. From then on, we were one, baptized in His Spirit, united as His body by the bonds of love and of the Holy Spirit under divine orders. ${ }^{58}$

In the afternoon, Martin Gensichen, who was the guest speaker, ${ }^{59}$ explained the manifestations which had occurred that morning, in connection with the meaning of being baptized in the Holy Spirit referring to 2 Chronicles 1:7.

\subsection{Setting up the Literature Mission}

The Berlin Volksmission made literature mission its major field of activity. When, after moving to Höchstestraße, they had been assigned to a new police precinct, and their relationship to the government offices had continually improved, they were only observed sporadically then. The officers attended the meetings in plain clothes. ${ }^{60}$ A bookstall could be maintained again which was registered with the Reich's Literature Chamber via the Liebenzeller Mission, with whom the Volksmission had a good relationship then. ${ }^{61}$ Tracts were bought from the Swiss "Verein für entschiedenes Christentum in Basel", but this meant nothing more than a meagre temporary solution to Fix. The entire German people should rather become acquainted with the message of the full salvation in Christ, in contrast to the "waves of national socialist propaganda flooding the people". ${ }^{2}$ Fix writes:

Thus, I beseeched God by prayer and fasting to give us a literature mission, also making a clear promise not to seek any advantage for myself, not even to print a post office bank account onto any piece of literature (I had realised that here and there in the Kingdom of God, money, together with a post office bank account, played quite a negative role!); if possible, the tracts should be distributed free of charge. $^{63}$

Shortly after this, a farmer living near the German-Polish border, came to see Fix. His name was Otto Gohlke. Together with some brethren, he had founded the Meseritzer Schriftenmission publishing tracts and brochures. As they could not present themselves so well, they asked Fix to take over the editorship and the printing in Berlin. Besides publishing the tracts, they also wrote a prophetic statement on the People of Israel which "got lost in the

\footnotetext{
${ }^{58}$ Fix, K., Preiset mit mir den Herrn op. cit. p. 22

59 Martin Gensichen, born in 1879 as a son of the Berlin Director of Missions, had accepted Christ on 3 December 1900 through the ministry of Stöcker. Already in 1905 he had received a baptism in the Holy Spirit of the kind that Torrey taught. Working under Ohly in the Berlin city mission, he got into a conflict with him, because he made him write down his sermons (Fleisch, P., Geschichte der Pfingstbewegung in Deutschland von 1900 - 1950, p. 83). As a man who had travelled the USA, Canada and England, he was "privileged to come to know the great Donald Gee" (Dietze, R. "Schwimmgnade" nicht "Knöchelgnade", unpublished ordination paper, Erzhausen, archive of the BFP-Archiv, 1993, p. 13)

${ }^{60}$ Fix, K., "Aus dem Kleinsten sollen tausend werden...” op. cit. p. 10

${ }^{61}$ Fix, K., Preiset mit mir den Herrn op. cit. p. 23 In the constitution of 1938, section 8, it is remarked that "Regarding correspondence, the leader of the [literature] mission has been personally incorporated into the Society of the German Reich's Booksellers (belonging to the Reich's Chamber of Written Issues) through the Liebenzeller Mission, Bad Liebenzell, under VA 207/BII/19231.

${ }^{62}$ Fix, K., “Aus dem Kleinsten sollen tausend werden...” op. cit. p. 10

${ }^{63}$ ibid. p. 11
} 
mail". Not only did they never get back the paper, but soon after, the "Meseritzer Schriftenmission" was banned. ${ }^{64}$

Fix then edited literature from his own publishing house ${ }^{65}$. They were distributed with the following remark printed on them: "These tracts are distributed free of charge. Previous issues will be mailed, if the address is submitted. Please, see that these tracts are spread far and wide, pray for this work." 66 The first 5000 tracts cost 60 DM.

\subsection{The GESTAPO Confiscate "Grauen, Grausen"}

The fourth tract with the provocative title "Grauen! Grausen! Wehe denen, die auf der Erde wohnen..." ["Terror! Horror! Woe to those who live on earth ..."] is a testimony of Fix's prophetic vision of the coming catastrophes of World War II. Fix writes about the birth of this tract:

Concerning the tract "Grauen! Grausen!" my heart was unusually troubled. I heard many prophecies, visions and messages about the coming disaster. It had been revealed to me, and I would have liked to once more warn everybody. Yet, I knew that this way I would certainly ask for problems, as on the opposite side the "Millennium of Hitler" was being proclaimed. ... Finally I said to myself: If you live in a house and you know a fire has broken out, you must shout "Fire!" at least once, even if the others say, "Be quiet, everything is completely fine. ${ }^{67}$

When the first edition of 5000 had already been distributed, the GESTAPO confiscated the tract, taking the second edition directly from the press to their headquarters. Yet, neither the organisation nor the literature mission were banned, on the contrary it was rather spread all over the world due to contacts with the Swedish evangelist E. Grunewald. Until July 1939, when the literature mission was forbidden, more than two million large, four-page tracts had been sent to twelve countries, even as far as Canada and Brazil. One should remember that in Germany, free distribution of Christian tracts was prohibited then because of "causing public offence", and every circular letter and tract had to bear the warning "Public distribution of these tracts is forbidden". In July 1939, the entire literature mission was banned for good. ${ }^{68}$ Fix comments:

\footnotetext{
${ }^{64}$ Fix, K., Preiset mit mir den Herrn op. cit. p. 23

${ }^{65}$ The tracts had to bear the imprint, "Karl Fix, Deutsche Volksmission entschiedener Christen, Berlin N 58, Chorinerstr. 61" (Fix, K., "Lasset uns fortfahren mit der Heiligung in der Furcht des Herrn" No. 11, unknown date).

${ }^{66}$ Fix, K., Preiset mit mir den Herrn op. cit. p. 24

${ }^{67}$ ibid. p. 25

In 1955, looking back, Fix wrote: "When before the past World War, Mussolini paid his first official visit to Hitler in Berlin, about two million people had gathered on the Maifeld at the same time. That day, the "Führer" pronounced to all the world: "If tomorrow there is a war in Europe, there will be no Jews left in Europe the day after tomorrow!" All over the world this statement had been heard. Yet, nobody had the power to prevent this catastrophe. I myself was just busy writing a tract of warning at that time. With this brochure, I wanted to warn the people living in the regions that would be especially endangered in case of a war. According to the Bible, these had to be the European countries, where the greatest number of Jews lived. These were Poland, Romania and Hungary. At that time, the brochure was not granted any success. One tract of warning was confiscated by the GESTAPO right at the press" (Fix, K., Millionen Menschen müssen sterben! Ein Mahnruf an alle, Karl Fix Verlag Deutsche Volksmission entschiedener Christen, Schorndorf, 1955 (VII. edition 1962) p. 66).

${ }^{68}$ One of the reasons was the pacifist message, documented by statements such as "Love your enemies ..." (Fix, K., “Aus dem Kleinsten sollen tausend werden...” op. cit. p. 18)
} 
You need not have any illusions: World War II was about to begin. For months I had already had a service-record book with a call-up for the first day of mobilisation. Thus, I wrote a circular farewell-letter to all my friends of the literature mission quoting the wonderful word of comfort from Hebrews 13:5b and made a little package of tracts for everyone. This was my last big distribution of literature in the Third Reich. The next day I became a "Driver" in the Third Battery A. R. 176 Potsdam. ${ }^{69}$

The consequence of this last distribution of literature was a thorough search of the Fix' house, where almost all scriptures were confiscated. The reply to Erna Fix's protest, "My husband on the battlefield will be overjoyed when I write to him what has happened" was, "He is lucky to be there, otherwise we would take him with us". ${ }^{70}$

\subsection{All Pentecostal Churches are Banned}

Although between 1935 and 1945 the Volksmission was continuously under GESTAPO surveillance, it was not banned; but the Pentecostal Churches were. When raising one's hands for prayer and praise was later misunderstood as an imitation of the "Hitler salute", Fix would refrain from it. He would also resist the requests made by other Pentecostal Churches to join their confederation in order to find protection from being banned referring to Isaiah 8:12-13 (The Lord Almighty is the one you are to regard as holy, he is the one you are to fear, he is the one you are to dread ..."). ${ }^{71}$

\subsection{Branch Churches are Founded}

Fix had a constant desire of founding new churches. Thus, branch churches, such as those in Birkenwerder, Friedrichsfelde, Borkheide, Klein-Machnow and Moabit were founded in Greater Berlin. ${ }^{72}$ On his "trips to Saxony" he would travel to Zittau, Groß-Schönau and Waltersdorf. Often, healings accompanied the founding of new churches. ${ }^{73}$

\subsection{The "Weckhof" in Southern Germany}

In 1935, Fix came into contact with the "Weckhof" through his relatives living in southern Germany. It was a tiny, inconspicuous hamlet in Hohenlohe, close to his birth place of Kupferzell. There, he helped in strengthening the young church. ${ }^{74}$ The founder of the Weckhof church, Marie Primmer ${ }^{75}$, nee Wolf (1873), emigrated to America towards the end of the nineteenth century. She must have heard of the revival taking place in Los Angeles in

\footnotetext{
${ }^{69}$ Fix, K., Preiset mit mir den Herrn op. cit. p .29

70 ibid. p .30

${ }^{71}$ This way, Fix had also put it in section 7 of the constitution of 1938: “As the D.V.e.C. have made it their goal to serve the public without any obligations to a certain denomination - in their midst, are Protestants, as well as former Roman Catholics, Baptists, Methodists, Free Churches etc. - they will per se not promote any acquisition of members."

72 Ros H. und Kaupp G. (eds) Missionarisch in die Zukunft - 50 Jahre Volksmission entschiedener Christen 1945-1995, (Volksmission entschiedener Christen e.V., Stuttgart, 1995), p. 65

${ }^{74}$ Fix, K., Preiset mit mir den Herrn op. cit. pp. 34-35

${ }^{74}$ Breuninger, W., 50 Jahre Missionsgemeinde entschiedener Christen e.V., (Weckhof, Missionsgemeinde Weckhof e. V., 1975), p. 13

${ }^{75}$ In Breuninger, W., 50 Jahre Missionsgemeinde entschiedener Christen e.V, op. cit., the family name of the founder is said to be "Brümmer". Yet, the correct name is "Primmer" according to a letter written by Taubert, M. as of 26 February 2001, where he mentions a letter written by hand with the sender's name being clearly readable as "Primmer".
} 
1906. In July 1925, she returned to Germany for a two-year stay. In the homes of her relatives she would conduct services reading and explaining the Word of God. Her niece, Rosa Munzinger, relates how already on 9 August 1925, three young persons "were baptized in the Holy Spirit and spoke in tongues". 76 As the revival movement was harshly attacked by the state church, the believers left the church and on 23 June 1928 founded the registered society "Freie Pfingstgemeinde Weckhof e.V." ${ }^{77}$ Georg Breuninger was called to be their leader. Having attended Bible seminars conducted by Benjamin Schilling ${ }^{78}$ in Berlin, he got into contact with churches in Leipzig, Thuringia, Switzerland and Vienna. In the years between 1931 and 1939 the brethren Benjamin Schilling, Ernst Hebeisen and Hans Lack (Switzerland), as well as Karl Fix, who called the "Weckhof" his other spiritual home, ${ }^{79}$ would come to preach there. ${ }^{80}$ The brochure written for their $50^{\text {th }}$ anniversary witnesses to the endurance of this church and the astonishment of the American occupational forces at the end of the war:

\begin{abstract}
As right from the beginning the whole village had rejected national socialism, neither a flag, nor a swastika, nor a Hitler portrait could be found in any household. When the commanding officer entered the room in the Breuningers'/Eisseles' house that was used for the services, he immediately realised, by the way it was arranged and equipped, that it was a sanctuary. He was very surprised and glad by the explanation that there was a local Pentecostal church. Immediately he ordered the whole village with all its inhabitants and the numerous evacuated persons to be spared... There were no thefts, lootings, evacuations etc. ${ }^{81}$
\end{abstract}

\title{
2.15 The Outbreak of World War II
}

At the end of August 1939, Fix was conscripted by telegram. He assigned the subsidiary church leadership to Fritz Döhring. Rudolf Lehmann from the Steglitz church was entrusted with the preaching ministry. After having served on the western front line for one year, his company was transferred to the eastern areas as an occupation unit. From there, he had to guide an ammunition supply convoy via Hungary, Rumania, Bulgaria to the Russian winter front line. Weakened by the Wolhynian Fever, which had most likely been caused by a gunshot wound, he was finally admitted to a German military hospital on 20 April 1942, which saved him from having to go to Stalingrad. ${ }^{82}$ Fix considered it a miracle that a comrade managed to get a transfer to the staff headquarters OKW (Oberkommando der Wehrmacht) ${ }^{83}$ for him. He had to serve in the coding department, which was a secret service branch of the

\footnotetext{
${ }^{76}$ Munzinger, R., Augenzeugenbericht über die Entstehung der Weckhof-Gemeinde, unpublished typoscript, Künzelsau, 1998 R. Munzinger writes how her 11 year-old brother prophesied after having received the Baptism of the Holy Spirit, "that there would still be many coming to the Weckhof, and that they would be coming from afar".

${ }^{77}$ Breuninger, W., 50 Jahre Missionsgemeinde entschiedener Christen e.V, pp. 3-5

${ }^{78}$ Schilling was in Weckhof in the years 1928/29. Miraculous healings having happened under his ministry have been reported (Taubert, M., Info über Weckhof-Gemeinde, unpublished typoscript, Künzelsau, 1998).

${ }^{79}$ Fix, K., Preiset mit mir den Herrn op. cit. p. 34

${ }^{80}$ Taubert M., Gemeinde auf dem Weg 75 Jahre Missionsgemeinde entschiedener Christen Künzelsau, Künzelsau, Missionsgemeinde e. C., 2000, p. 8

${ }^{81}$ Breuninger, W., 50 Jahre Missionsgemeinde entschiedener Christen e.V, p. 8

${ }^{82}$ Interview with Johannes Fix on 5 June 2001.

${ }^{83}$ The OKW was the highest administrative and command level of the German armed forces.
} 
foreign broadcasting surveillance. ${ }^{84}$ As he had to work mainly at night, he could further attend the services and lead the church through the hardest time of need, ${ }^{85}$ until in April 1945 his military headquarters were transferred to the south, $50 \mathrm{~km}$ away from Salzburg. The leading general handed over his troops to the Americans, Fix was granted an early discharge to his southern German home, where his family had already been evacuated to in $1943 .{ }^{86}$ Their former home had been destroyed and all their possessions had been looted and burnt, so that his wife with their two children had to be put up in the school building of the neighbouring village. $^{87}$

Just during the hard times of bombings, many people came to believe in Christ. Thus, even the General Superintendent and Bishop of the Berlin Lutheran Church, Kurt Scharf, published the testimony of the former social democratic member of the Prussian parliament, Mrs Dr. Hildegard Wegschneider, titled Die verborgene Gemeinde ["The Hidden Church"], in his special brochure "Wir sind doch Brüder" ["But we are Brothers"] celebrating the $1^{\text {st }}$ Kirchentag, which is the national convention of the Lutheran Churches in Berlin. He introduced this testimony with these words: "The fact that Berlin has been revived after the horrible war of nerves during the Hitler regime and the last two months of World War II, is due to its hidden assembly of Christians."

\subsection{A New Home - the Lazarus Hospital}

On 18 March 1945, shortly before the total capitulation on 8 May 1945, all residential areas around Friedrichshain, and thus the hall of the Volksmission as well, burst into flames when the bombs were showered upon the city. ${ }^{88}$ As the Volksmission also used a small hall in Moabit, meetings could be held there temporarily, until finally the entire church was given a place to meet in the chapel of the Lazarus Hospital in Bernauerstraße for 3 years and 6 months. Some faithful deaconesses feeling at home in the Volksmission had helped obtaining it.

As Fix's profession could not actively contribute to the rebuilding of the nation, he was refused the permanent right to stay by the authorities of the eastern section. This caused him to make Vaihingen/Enz in the state of Württemberg his place of residence. ${ }^{89}$ Nevertheless, he visited the Berlin Church which he had entrusted to August Witt, quite often. ${ }^{90}$ On 8 September 1946, a baptismal service could be conducted again. ${ }^{91}$

\subsection{How the Volksmission came to Stuttgart}

Shortly after World War I, a sister in Christ - her name is not known any more - who had come to know a Pentecostal church during a longer stay in America, spoke about the Word of God every Sunday afternoon in a "House Meeting" in Hördtstraße 2, Stuttgart-Zuffenhausen.

\footnotetext{
${ }^{84}$ Here, his office was directly under Admiral Wilhelm Canaris (1887-1945), head of the Department for Defense in the Ministry of War. As a resistance fighter, Canaris was executed in the KZ Flossenbürg on 9 April 1945 (oral information given by Herbert Ros on 9 April 2001).

${ }^{85}$ Fix, K., Preiset mit mir den Herrn op. cit. p. 39

${ }^{86}$ Fix, K., 20 Jahre Volksmission entschiedener Christen Stuttgart September 1945 bis September 1965 - Weg und Werk -, (Schorndorf, Verlag Deutsche Volksmission entschiedener Christen, 1965), p. 3

${ }^{87}$ ibid. p. 3

${ }^{88}$ Gast, H.J., Geschichte der Volksmission Berlin op. cit. p. 1

${ }^{89}$ Fleisch, P., Geschichte der Pfingstbewegung in Deutschland von 1900 - 1950, p. 364

${ }^{90}$ Fix, K., Preiset mit mir den Herrn op. cit. p. 53

${ }^{91}$ Gast, H.J., Geschichte der Volksmission Berlin op. cit. p. 1
} 
This house group got in touch with the "Freie Pfingstgemeinde Weckhof e.V." A special highlight was a Bible study held there by Karl Fix in the year 1937 or $1938 .{ }^{92}$ This house group was to become a second home to him.

At the same time, a prayer meeting of a similar kind developed in Brackenheimer Straße, which is about 10 minutes' walking distance from the Hördtstraße. Here, the "meetings" were held by Paula Gassner, who had experienced the Baptism of the Holy Spirit during a stay in Kensington Temple, London. ${ }^{93}$

When he was released from the American concentration camp on 18 June 1945 and sent to Heilbronn, Paula Gassner contacted him because of publishing matters. As the speaker, who had been invited for the first public meeting of the Stuttgart house groups, had not turned up, Fix was spontaneously asked to preach the word in the meeting on Sunday, 9 September 1945 in a hired hall of the Hohenstein school, which was attended by around 50 people. ${ }^{94}$

In 1946, the duo became a triumvirate when Karl Keck, a Liebenzell missionary, joined them. They took over the responsibility for the meetings and for missionary activities. In September 1946, the first public baptism of 250 people, which was accompanied by many healings, took place in the Inselbad in Stuttgart-Untertürkheim. ${ }^{95}$ As a result of tent and open-air meetings, the Volksmission rapidly spread in southern Germany, so that at the present time, there are about 60 Volksmission churches in southern Germany besides the Berlin enclave.

\section{Concluding Remarks}

Karl Fix died suddenly and unexpectedly on 19 January 1969, shortly after celebrating with his church in Berlin their $35^{\text {th }}$ anniversary. Even Dr. Kurt Hutten, member of the Protestant Church Council and sect expert, who had often harshly criticised the Volksmission as a Pentecostal Movement in his contributions appearing in the "Evangelisches Gemeindeblatt" ["Periodical of the Lutheran Church"], ${ }^{96}$ had to admit in his writings that Karl Fix was being evaluated very positively by several ministers regarding his manner of preaching.

The history of the Volksmission, which, due to its membership in the Bund Freikirchlicher Pfingstgemeinden (BFP) ["Federation of Pentecostal Churches in Germany"] has got the rights of a public incorporated body since 1988, is inseparably connected with the work of Karl Fix. Until breathing his last, he had inspired and motivated the fellowship of about 60 churches, granting them a sound theological basis. His care for senior citizens and for those in need led to the birth of the "Haus Elim, Alters- und Erholungsheim Leutenbach e.V." under his leadership in 1962, by which two homes for the elderly and for those in need of care are being run today. ${ }^{97}$ Thanks to his concern for foreign missions, the Volksmission, as the first

\footnotetext{
${ }^{92}$ Ros, H., "40 Jahre Volksmission entschiedener Christen Stuttgart” in Volksmissionar, No. 11, October, 1985, p. 4

93 Gassner, P., In des Töpfers Hand - Die Autobiographie von Paula Gassner, Selbstverlag der Biblischen Glaubens-Gemeinde, Stuttgart, 1977, p. 31

${ }^{94}$ Further details can be found in the testimony of the shoemaker Otto Stegmüller in Ros H., Der Mann aus China - Leben und Wirken des Oskar Siering, Missionsverlag Gottlob Ling, Pforzheim, 1982, pp. 114-115

95 ibid p. 19

${ }^{96}$ Fix, K., "Der Fromme-Leute Schreck: Die Pfingstbewegung", Der Volksmissionar, No. 20, 1951, p. 2

${ }^{97}$ Ros H. und Kaupp G. (eds) Missionarisch in die Zukunft, op. cit. p. 29
} 
Pentecostal Church in Germany after World War II, was enabled to send Heinz Battermann to Kenya as a missionary in $1956 .^{98}$

Fix was a bold prophetic warning voice in his time when almost the whole of Germany applauded the "Fuehrer" and when every kind of criticism could endanger one's life. May his unshakeable faith and his consecrated life spur the next generation into unreserved dedication to their Lord Jesus Christ.

${ }^{98}$ ibid p. 134 